DOI: 10.32370/IA_2021_06_13

\title{
Ethnocultural Self-Identification as an Object of Cultural Research
}

\author{
Golub Kateryna Vadymivna, \\ graduate student, \\ Kyiv National University of Culture and Arts
}

\begin{abstract}
Scientific views on the processes of constructing ethnocultural self-identification in culturological discourse are researched and systematized. The concept of "ethnocultural self-identification" is specified, the basic conceptual approaches to research of ethnocultural self-identification are considered and analyzed. It is revealed that ethnocultural self-identification is determined by a complex set of factors: historical, social, economic, political, psychological and cultural. In modern culturological discourse, ethnocultural self-identification is seen mainly as the search for and discovery of traditional values in the context of everyday space. Despite the differences in the modern scientific dimension of approaches to the problem of ethnocultural self-identification, most researchers agree that this phenomenon is a complex process of identification with a particular ethnocultural group, assimilation of personality to a particular image, which occurs as an individual part of it and experiencing one's own devotion to it, not autonomously, but together with other processes of human activity (social, labor, political), in the process of communication and the context of everyday behavior. Constantly comparing their own actions and deeds with the norms and patterns of a particular ethnocultural group, the individual positions them as standards, criteria of behavior, self-reflection.

The author concludes that ethnocultural self-identification is one of the most important human values, because fixing the unity of individual interests with the interests of its ethnic community ensures self-preservation as a person and as an individual, contributes to the needs of self-affirmation and self-expression.
\end{abstract}

Key words: ethnocultural self-identification, ethnoculture, identity, personality, culturological discourse.

Актуальність дослідження. Глобалізаційні процеси, характерні для сучасного періоду розвитку цивілізації, що створюють загрозу тотальній уніфікації багатьох культур, актуалізують питання збереження їх унікальності та своєрідності. Однією 3 форм реакції традиційних культур на глобалізацію стала локалізація - комплекс процесів, що виражається в прагненні багатьох культур до збереження власної специфіки, відновлення втрачених традиційних аспектів, до реконструкції основних етапів власного культурогенезу, включно з ланцюгами їх історичної спадковості. Проте, на думку сучасних дослідників, це створює проблему виявлення і збереження традиційних основ локальних культур у глобальному світі, через реалії сучасності та особливості процесів культурогенезу, сенс яких полягає в єдності збереження, відтворення, розвитку та постійного оновлення культури [11, с. 3]. 
Сучасна культура характеризується тим, що, 3 одного боку, руйнуються відмінності між культурами та індивідами, що призводить до кризи самоідентичності, а з іншого, спостерігається процес збереження та зростання етнічної самосвідомості у зв’язку з соціальними трансформаціями. Це зумовлює i водночас, у контексті перерахованих вище сучасних процесів, що призводять до різких змін локальних культур (у тому числі культур, які відрізняються етнотрадиційною та територіальною своєрідністю), актуалізує проблематику розуміння, функціонування та розвитку етнокультурної самоідентифікації.

Аналіз публікацій. Важливість та багатоаспектність проблематики етнокультурної самодентифікації зумовлює звернення до неї представників різних гуманітарних наук - соціології, педагогіки, політології, етнології. Наприклад, згадаємо наукові праці С. Вінтоніва «Принципи формування етнокультурної самоідентифікації» (2011 p.), І. Гаюк «Особливості формування етнокультурної самосвідомості вірмен на українських землях» (2019), Л. Макарової «Етнічна самоідентифікація студентської молоді як творчий процес» (2013), Н. Марчук Особливості етнічної самоідентифікації польської етногрупи в умовах національно-культурного відродження України» (2011), Г. Сукачової «Чинники формування етнічної самоідентифікації населення сучасної України» (2011) та ін., в яких аналізуються різноманітні аспекти означеного питання.

Проте, незважаючи на неабиякий науковий інтерес до проблеми етнокультурної ідентичності у вітчизняному академічному вимірі, на сучасному етапі в українській науці не вистачає комплексних культурологічних досліджень, присвячених специфіці етнокультурної самоідентифікації.

Мета статті - виявити специфіку змістового аспекту категорії «етнокультурна самоідентифікація» та понять безпосередньо пов’язаних з нею в межах культурології.

Виклад основного матеріалу. На сучасному етапі розвитку гуманітарного знання існує багато напрямів, що вирішують питання етнічної ідентифікації, виходячи 3 можливостей вибору різних дисциплін та методологій. Передусім постає питання вибору традиції, якої дослідник планує дотримуватися, в процесі розробки проблеми самоідентичності, що зумовлено важливістю, складністю та багатоаспектністю самого явища, неоднозначним трактуванням поняття. Етнокультурна самоідентифікація $€$ центральною категорією етносоціології, також вивчається іншими суміжними науками, 
зокрема етнологією, антропологією, соціологією та ін. Культурологія, як синтетична наука, що виникла на межі соціогуманітарного пізнання, зумовлює формування цілісного комплексу наукових уявлень про цілісність культури та є каталізатором процесу інтегрування і взаємодії різноманітних галузей знань в контексті дослідження певного об'єкту.

Культурологія включає етнокультуру в галузь свого дослідження - складного комплексу наукових дисциплін, методологій та підходів до культурологічної проблематики, розглядає іiі як культуру людей, пов’язаних спільністю походження та проживання.

У контексті даного дослідження акцент зроблено на визначення змістового аспекту категорії «етнокультурна самоідентифікація» та понять, безпосередньо пов'язаних з нею в межах культурології.

Характерною тенденцією світового масштабу в другій половині XX ст. стало осмислення власної етнічної ідентичності - приналежності до певного етносу, проте проблематика їі розгляду в академічному вимірі чітко означилася лише на початку доби постмодерну, що, на думку дослідників, зумовлено процесом глобалізації та проблем Захід-Схід. Так, Л. Науменко наголошує, що природа походження самоідентичності людини має два соціально-психологічні спекти:

- уніфіковано орієнтований (будь-яка людина від народження належить до певного цивілізаційного, культурного, етнічного, мовного, релігійного суспільства, тому природно засвоює навколишню його цивілізаційну реальність, набуваючи відповідної культурної ідентичності шляхом пізнання себе частиною цього суспільства);

- диференціально орієнтований (відповідно до соціально-психологічної теорії відмінності, люди визначають власну приналежність, цивілізаційну ідентичність за допомогою того, чим вони не є в категорії «Ми - вони», наприклад, у процесі взаємодії українця з італійцем вони будуть ідентифікувати себе як українець та італієць, а у випадку їх взаємодії з двома арабами, громадянами Сирії та Сгипту - як європейці та араби) [6, с. 78].

У контексті даного дослідження вважаємо за доцільне уточнити поняття «ідентичність», «ідентифікація», «самоідентифікація» та «етнокультура», що $\epsilon$ складовими поняття «етнокультурна самоідентифікація». 
Ідентичність - це триєдиний духовно-душевно-тілесний статичний, стабільний стан людини; певний стан, що означає поступове перенесення індивідом на себе якостей спільності, в якій індивід формується як особистість. Г. Попова акцентує на відмінності понять «ідентичність» та «ідентифікація» («самоідентифікація»), наголошуючи, що процес ідентифікації відбувається постійно, а ідентичність як стан наступає час від часу, «потім додається новий рід ідентичності, таким чином, поступово формується етнокультурна ідентичність людини - різноманіття та багатство як цілісність його внутрішньої самосвідомості» [8].

В культурологічній науці виділяють поняття «культурна ідентичність» оформлення у вигляді історії, міфів, релігії, духовного життя народу прагнення зберегти та захистити культурні надбання. На думку дослідників, культурна ідентичність - це проект життя індивіда або народу, спрямований на майбутнє, що постійно переглядається та оцінюється, а найголовнішими ознаками ідентичності особистості є відмінність від інших та цілісність [3, с. 74]. Те саме можна стверджувати про етнос та етнічну особистість, відповідно у цьому зв'язку стає можливим говорити також і про етнокультурну ідентичність, вводячи у наведене визначення замість поняття «народ» поняття «етнос». Головним аргументом введення поняття етнокультурної ідентичності $\epsilon$ те, що ані людина, ані культура без етнічної приналежності практично не існує, а етнос генетично пов'язаний з певним природним середовищем із характерними особливостями та біокультурним мовним одноманіттям [8].

Оскільки ідентичність можна розуміти як постійне, повсякденне поведінкове (діяльнісне) відтворення власної приналежності до групи, етнічна самоідентифікація означає «інтеріоризацію» якостей етнічної спільності, що сформовані в процесі етногенезу [5, с. 21]. На думку П. Герчанівської, субстанційна, внутрішня основа людини визначається за допомогою поняття «самоідентифікація», набуваючи в цьому аспекті значення «придбання індивідом властивості засвоювати культурно-історичний досвід суспільства, обираючи його орієнтиром власної життєдіяльності» [2, с. 117].

Сучасна культурологія виходить 3 того, що загальний масив національної культури включає в себе всі форми, способи та результати діяльності, що побутують в даному етносі, а також всю сукупність культурних явищ, що створюються та споживаються етносом, включно з іншоетнічними запозиченнями, комплексами та 
елементами інтернаціональної загальносвітової культури, локальними культурними рисами, що характерні для сусідніх або споріднених етносів [4, с. 55].

На відміну від загальної культури, специфічна етнічна культура охоплює лише те, що сприймається самим етносом та його сусідами як характерна саме для нього i асоціюється з ним. Отже, етнокультура охоплює переважно галузь побуту та способи повдякденної життєдіяльності людини, торкаючись, передусім, соціокультурних особливостей локальної однорідної спільноти. Основу етнокультури складають обряди, звичаї, поведінкові особливості, характерні народні промисли та інші стійкі риси побуту, що передаються з покоління в покоління.

Незважаючи на те, що на сучасному етапі розвитку суспільства етнокультура не завжди функціонує як цілісна система, окремі іiі елементи (наприклад, етнічна самосвідомість, традиції та звичаї, символи) завжди виступають як необхідні складові системної цілісності будь-якого етносоціального організму.

Е. Цанева акцентує на тому, що термін «етнічний» як науковий конструкт пропонує об'єднати зміст етносу та етнічності та означити минулу і теперішню специфіку та процеси феномену етнічної ідентичності. Дослідниця також пропонує використовувати етносимволізм для впорядкування та сортування, відслідковування динаміки та виявлення положення різноманітних компонентів ідентичності [14, p. 1].

На думку дослідників, етнокультура являє собою органічну цілісність, основою якої є культурні універсалії, що створюють цілісний узагальнений образ людського світу. О. Тучина наголошує на тому, що для аналізу феномену етнічності необхідно застосувати цілісний підхід, оскільки, з одного боку, етнічна культура не може існувати поза своїми носіями, а з іншого, сукупність людей не може бути етнічною спільнотою поза відповідної культури [10, с. 256].

Етнічна самоідентифікація - це високий та широкий рівень особистої самоідентифікації, тобто специфічного психологічного процесу, за допомогою якого певний суб'єкт набуває та привласнює певні якості, атрибути іншого суб'єкту/об'єкту та перетворює себе (частково або повністю) за їх взірцем, починаючи сприймати себе унікальним, когерентним, єдиним у часі та просторі [12, с. 51].

Дослідники акцентують на тому, що етнопсихологічною основою процесу етнокультурної самоідентифікації особистості виступають етнічні константи та ціннісні 
домінанти, що являє собою внутрішній культурний стрижень відповідного етносу. Осмислення етнічної приналежності забезпечується на основі освоєння особистість елементів власної культури, з яких головними виступають цінності та норми життя, діяльності та поведінки.

Натомість на думку Г. Сукачової, оскільки етнічна самоідентифікація відбувається в процесі громадської, трудової та політичної діяльності, в тому числі й на побутовому рівні [9, с. 227], недоцільно розглядати її суто в духовно-моральному сенсі.

Х. Вільданов стверджує, що незмінною константою сутності етнокультурної самоідентифікації є ідея духовної єдності етносу, заснованої на національних цінностях. Дослідник наголошує на тому, що ідентифікаційний потенціал національних цінностей, що фіксує факт психологічної та соціальної самобутності певного етносу та його відмінності від інших аналогічних цінностей, передбачає єдність всіх членів етносу, які об’єднані спільними ідеями, цілями та установками [1, с. 216].

У структурі етнічної ідентичності, як складової частини соціальної ідентичності, психологічної категорії, що належить до осмислення власної приналежності до певної етнічної спільноти, дослідники виділяють два основних компоненти: когнітивний та афективний, відносячи до першого знання, уявлення про особливості власної групи та осмислення себе як їі члену на основі певних характеристик, а до другого - оцінку якостей власної групи, ставлення до членства в ній, її значущість [7, с. 32].

На думку Д. Юрочкіна, аксіологічні основи етнокультурної самоідентифікації доцільно розглядати крізь призму поліетнічного простору, що сприяє осмисленню історії та культури етносу в контексті соціально-психологічних властивостей націй, а також напрацюванню оптимальних умов збереження та розвитку націй та етнічних культур [13, c. 292].

У межах суб’єктного підходу етнокультурна самоідентифікація може розглядатися як освоєння особистістю нормативно ціннісного потенціалу етнокультурної традиції та побудови власних сенсів у межах іï рівня. Такий підхід дає змогу встановити, що етнокультурна самоідентифікація передбачає формування:

- ціннісно-нормативного рівня етнокультурної традиції;

- рівня буденності, норми, характерної для даної етнокультурної традиції;

- уявлення про себе в межах етнокультурних норм та цінностей; 
- ціннісно-сенсового аспекту етнокультурної самоідентифікації.

Висновки. Етнокультурна самоідентифікація входить в коло найважливіших цінностей людини, оскільки фіксація єдності інтересів особистості 3 інтересами іiі етнічної спільності забезпечує самозбереження людини як особистості i як індивідуальності, сприяє реалізації потреб у самоствердженні та самовираженні.

Дослідження виявило, що в сучасному культурологічному дискурсі етнокультурна самоідентифікація розглядається переважно як пошук та віднайдення традиційних цінностей в контексті буденного простору. Незважаючи на відмінності наявних у сучасному науковому вимірі підходах до проблеми етнокультурної самоідентифікації, більшість дослідників сходяться у думці, що даний феномен - це складний процес ототожнення 3 певною етнокультурної групою, уподібнення особистості конкретному образу, що відбувається як переживання індивідом вкоріненості в конкретну групу, позиціювання себе іï частиною та переживання власної відданості їй, не автономно, а разом 3 іншими процесами людської діяльності (громадської, трудової, політичної), в процесі спілкування та в контексті побутової поведінки. Постійно порівнюючи власні дії та вчинки з нормами та зразками певної етнокультурної групи, індивід позиціонує їх еталонами, критеріями поведінки, саморефлексії.

Формування етнокультурної самоідентифікації, що є механізмом становлення етнокультурної ідентичності і детермінована складною сукупністю факторів: історичних, соціальних, економічних, політичних, психологічних та культурних, залежить від інтенсивності впливу та ступеня занурення особистості в «етнічний вимір».

\section{References}

1. Vildanov, Kh. S. (2014). National values in the structure of ethnocultural and national self-identification of an individual. Basic research, no. 9-1, pp. 214-218.

2. Herchanivska, P. E. (2013). Self-identification of man in modern socio-cultural realities. Culture of the peoples of the Black Sea region, no. 263, pp. 116-119.

3. Yerasov, B. S. (1994). Social Culturology: in 2 hours. Moscow.

4. Kozlov, V.I. (ed.). (1995). Ethnic and ethno-social categories: a set of ethnographic concepts and terms. Issue 6. Moscow: ISA RAN.

5. Nabok, I. L. (2009). Ethnic tolerance and identity. The reality of the ethnos. The role of education in the formation of ethnic and interfaith tolerance: a collection of articles on the 
materials of the XI International Scientific and Practical Conference. (St. Petersburg, April 1417, 2009). St. Petersburg: Asterion, pp. 18-24.

6. Naumenko, L. I. (1997). Ethnic identity. Transformation problems in the post-Soviet period. Ethnic psychology and society. Moscow: Old Garden, pp. 66-78.

7. Pankin, A. B. (2006). Formation of ethnocultural personality. Moscow: Publishing house of the Moscow Psychological and Social Institute; Voronezh: Publishing house NPO Modek.

8. Popova, G. S. (2013). Ethnocultural identification in the conditions of modern society. Contemporary research on social problems, no. 2 (22). http://dx.doi.org/10.12731/2218-74052013-2-30.

9. Sukachova, G. P. (2011). Factors of formation of ethnic self-identification of the population of modern Ukraine. Bulletin of the National Law Academy of Ukraine named after Yaroslav the Wise, no. 7, pp. 224-227.

10. Tuchina, O. R. (2015). Self-understanding of ethnocultural identity in different conditions of being of an ethnic group. Theory and practice of social development, no. 8, pp. 256-259.

11. Ulinova, I. Kh. (2019). Traditions in the modern culture of the Kalmyk ethnos. Abstract of Ph.D. St. Petersburg : St. Petersburg State Institute of Culture.

12. Huntington, S. (2003). Collision of civilizations. Moscow: AST.

13. Yurochkin, D. M. (2014). Ethnocultural self-identification of the individual in the polycultural space. Modern problems of science and education, no. 4, pp. 291-195.

14. Tzaneva, E. (2019). Ethno-Cultural Symbolism and Group Identity. In S. Ratuva (Ed.), The Palgrave Handbook of Ethnicity, pp 1-20.

\section{Translation of the References to the Author's Language}

\section{Список використаних джерел}

1. Вильданов X. С. Национальные ценности в структуре этнокультурной и национальной самоидентификации индивида. Фундаментальные исследования. 2014. № 9-1. С. 214-218.

2. Герчанівська П. Е. Самоідентифікація людини у сучасних соціокультурних реаліях. Культура народов Причерноморья. 2013. № 263. С. 116-119.

3. Ерасов Б. С. Социальная ккультурология : в 2-х ч. Москва, 1994. 312 с.

4. Козлов В. И. (ред). Этнические и этно-социальные категории : свод этнографических понятий и терминов. Вып. 6 / под общей редакцией академика Ю.В. Бромлея и профессора С. И. Вайнштейна.. Москва : ИЗА РАН, 1995. 216 с.

5. Набок И. Л. Этническая толерантность и идентичность. Реальность этноса. Роль образования в формировании етнической и межконфессиональной толерантности: 
сборник статей по матерыалам XI Международной научнопрактической конференции. (Санкт-Петербург, 14-17 апреля 2009 г.). Санкт-Петербург : Астерион, 2009. С. 18-24.

6. Науменко Л.И. Этническая идентичность. Проблемы трансформации в постсоветский период. Этническая психология и общество. Москва : Старый сад, 1997. C. 66-78.

7. Панькин А. Б. Формирование этнокультурной личности. Москва : Изд-во Московского психолого-социального ин-та.; Воронеж: Изд-во НПО Модэк, 2006. 279 с.

8. Попова Г. С. Этнокульутрная идентификация в условиях современного социума. Современные исследования социальных проблем. 2013. № 2(22). http://dx.doi.org/10.12731/2218-7405-2013-2-30.

9. Сукачова Г. П. Чинники формування етнічної самоідентифікації населення сучасної України. Вісник Національної юридичної академії України імені Ярослава Мудрого. 2011. № 7. С. 224-227.

10. Тучина О. Р. Самопонимание этнокультурной идентичности в разных условиях бытия этнической группы. Теория и практика общественного развития. 2015. № 8. C. 256-259.

11. Улинова И. Х. Традиции в современной культуре калмыцкого этноса : автореферат дис. канд. кульутрологии : 24.00 .01 / Санкт-Петербургский государственный институт культуры. Санкт-Петербург, 2019. 22 с.

12. Хантингтон С. Столкновение цивилизаций. Москва : АСТ, 2003. 603.

13. Юрочкин Д. М. тнокультурная самоидентификация индивида в пполикультурном пространстве. Современные проблемы науки и образования. 2014. № 4. C. 291-195.

14. Tzaneva E. Ethno-Cultural Symbolism and Group Identity. In S. Ratuva (Ed.), The Palgrave Handbook of Ethnicity, 2019. pp 1-20. 